\title{
ע Kansanterveys ja ekologinen kuorma
}

Ihmiskunta on saavuttanut merkittäviä kansanterveyden edistysaskeleita eri puolilla maailmaa. Terveyden edistymisestä on kiitetty muun muassa talouskasvua. Talouskasvuun liittyvällä kuluttamisella on kuitenkin ekologinen kääntöpuolensa: samaan aikaan kun ihmiskunnan terveys on parantunut, on ihmiskunnan ekologinen jalanjälki kasvanut ja ekosysteemit ajautuneet kriisiin.

Tarkastelemme kansanterveyden kehitystä ja ekologista kuormaa 33 OECD- ja BRICS -maassa 53 vuoden ajanjaksolla. Tarkemmin kysymme, miten kansanterveys ja ekologinen jalanjälki ovat kehittyneet vuodesta 1960 vuoteen 2015. Tavoitteemme oli selvittää, onko löydettävissä maita, joissa sekä elinajanodote tai vastasyntyneiden eloonjäänti että ekologinen jalanjälki ovat kehittyneet positiivisesti. Pohdimme tuloksia ympäristövaltio -kirjallisuuden valossa.

Tutkimuksessa käytetty paneeli-aineisto sisälsi tiedot 33 maan ekologisesta jalanjäljestä, imeväiskuolleisuudesta ja elinajanodotteesta vuosilta 1960-2015. Ekologisesta jalanjäljestä laskettiin kullekin maalle ajanjaksolta vuosikeskiarvo. Kansanterveyden osoittimista analysoitiin muutosta vuosien 1960 ja 2015 välillä. Koska kansanterveyden lähtötaso ja siten kehityspotentiaali oli maissa erilainen, suhteutettiin absoluuttinen kehitys teoreettiseen maksimikehitykseen. Maakohtaisten analyysien jälkeen maat ryhmiteltiin suurempiin alueisiin tarkempaa ajallista analyysia varten. Tulokset esitetään hajontakuvioina.

Löysimme kestävän ja suhteellisen pienen ekologisen jalanjäljen maita, joissa kansanterveys on kehittynyt suhteellisesti enemmän, ja vastaavasti suuren ekologisen jalanjäljen maita, joissa kehitys on ollut vähäistä. Tulokset antavat viitteitä siitä, että hyvä kansanterveyden taso voidaan säilyttää ja terveyttä edistää myös niukemman kulutuksen oloissa. Nïn hyvinvointivaltioissa kuin alemman tulotason maissa on potentiaalia ympäristövaltioiksi, joissa huolehditaan sekä ympäristöstä että väestön terveydestä.

\section{ASIASANAT: kansanterveys, ekologinen jalanjälki, OECD, BRICS, ympäristövaltio}

\section{JUTTA PULKKI, MIKKO PERKIÖ, LAURI KOKKINEN}

\section{YDINASIAT}

- Aikaisemmista tutkimuksista tiedetään, että maiden kansanterveyden edistyessä ekologinen kuorma kasvaa.

- Tuloksemme osoittavat, että maa- ja aluekohtaiset erot kansanterveyden edistymisen ja ekologisen kuorman suhteessa ovat suuria.

- Kansanterveyden taso voidaan säilyttää ja terveyttä edistää myös kestävällä ekologisella kuormalla.

- Niin hyvinvointivaltioissa kuin alemman tulotason maissa on potentiaalia ympäristövaltioiksi.

\section{JOHDANTO}

Kansanterveyden edistämisellä on vakiintunut asema useimpien kansallisvaltioiden tavoitteissa ja toiminnassa. Eri puolilla maailmaa onkin viimeisten vuosikymmenien aikana saavutettu merkittäviä terveyden edistysaskeleita esimerkiksi elinajanodotteen kasvulla ja imeväiskuolleisuuden laskulla mitattuna [1, 2]. Vaikka elinajanodotteen kehitys on monissa maissa hidastunut, ja jopa kääntynyt laskuun [3], ja huolimatta maiden välisistä huomattavista terveyseroista, voi mennyttä vuosisataa pitää kansanterveyden kultaisena ajanjaksona [4]. 
Kansanterveys on lisääntynyt samanaikaisesti kuin maiden materiaalinen hyvinvointi, joka kytkeytyy puolestaan maiden taloudelliseen, teolliseen, teknologiseen ja tieteelliseen kehitykseen, sekä poliittiseen, sosiaaliseen ja hallinnolliseen vakauteen. Kansanterveyden edistyminen on liitetty erityisesti talouskasvuun [5,6]. Talouskasvun ja kansanterveyden positiivinen yhteys ei ole kuitenkaan yksioikoinen [7, 8, 9, 4]. Talouskasvulla näyttäisi olevan positiivinen vaikutus siihen asti, kun kansan perustavimmat tarpeet on tyydytetty [10, 70-76]. Alemman tulotason maissa talouskasvu voi edelleen lisätä kansanterveyttä esimerkiksi auttamalla alentamaan imeväiskuolleisuutta $[7,8,9]$, mutta korkeamman tulotason maissa kasvun lisäys ei tuota enää samassa suhteessa terveyttä $[7,9,11]$. Talouskasvun rajahyöty on siis laskeva. Lisäksi talouskasvulla on ekologinen kääntöpuoli [12, 13, 14, 15], josta puolestaan seuraa kansanterveyden heikentymistä [13, 14].

Samalla kun ihmiskunnan terveys on erilaisilla mittareilla parantunut, ovat maapallon muut ekosysteemit kuten ilmasto, vesistöt, maaperä ja eläinlajit ajautuneet kriisiin, monilta osin ihmisten toiminnan vuoksi [4]. Ihmiskunnan ekologinen jalanjälki, joka mittaa kulutuksesta aiheutuvaa ekologista kuormaa, on kasvanut 1960luvulta 2010-luvulle 190 prosenttia [16]. Vuonna 2018 suomalaisen ekologinen jalanjälki oli keskimäärin 4,8 globaalihehtaaria (gha) [17], kun kestävän jalanjäljen on arvioitu olevan tällä hetkellä 1,7 gha [18]. Kulutukseen perustuvaa talouskasvuajattelua pidetään keskeisenä syynä ekologisen jalanjäljen kasvuun ja tämän hetken ekokriiseihin, joita ovat muun muassa ilmastonmuutos, biodiversiteettikato, vesistöjen tuhoutuminen ja eläinlajien joukkokadot [19, 4].

Ekokriisit vaikuttavat suoraan ja epäsuorasti ihmisen terveyteen, mikä tekee niistä aikamme merkittävimmän kansanterveyskysymyksen ja tutkimuskohteen [13 14]. Esimerkiksi globaalissa mitassa eniten huomiota herättänyt ekologinen kriisi, ilmastonmuutos, vaikuttaa terveyteen ainakin kolmella tavalla. Säiden ääri-ilmiöt, kuten lisääntyneet helleaallot, vaikuttavat terveyteen suoraan aiheuttamalla ennenaikaisia kuolemia. Lisäksi lämpötilan nousun myötä ruoantuotanto on vaarantunut, lisäten nälänhätää. Kolmanneksi globaalin lämpötilan nousun vaikutuksesta taudinaiheuttajat leviävät uusille alueille ja tämä lisää todennäköisyyttä esimerkiksi malarian, denguekuumeen ja puutiaisen aiheuttamien sairauksien lisääntymiseen [13].

Kansanterveyden kohentuminen ja ekologisen kuorman kasvu ovat siis koko planeetan mittakaavassa tapahtuneet samanaikaisesti. Andy Haines [7] onkin osuvasti kysynyt, onko kansanterveyden edistäminen mahdollista ilman ekologista kuormaa. Aikaisemmat eri maita verranneet tutkimukset antavat tähän ristiriitaisen vastauksen. Tutkimukset ovat osoittaneet kansanterveyden edistymisen ja ekologisen jalanjäljen kasvun yhteyden eri maissa [12, 20, 21], mutta myös sen, että yhteyttä suuntaan tai toiseen ei ole [22]. On myös viitteitä siitä, että kansanterveys ei yksioikoisesti seuraa maan vaurastumista ja siihen yhteydessä olevaa kulutusta ja ekologista kuormaa $[8,12,20]$. Lisäksi terveyden edistymistä voi tapahtua myös pienen kulutuksen maissa $[8,7,12$, 20]. Näiden aikaisempien tutkimusten aikasarjat päättyvät 2000-luvun alkuun, ja on oletettavaa, että sekä kansanterveydessä että ekologisessa jalanjäljessä on tapahtunut muutoksia myös tämän jälkeen.

Tarkastelemme tässä tutkimuksessa kansanterveyden ja ekologisen kuorman kehitystä OECD- ja BRICS (Brasilia, Venäjä, Intia, Kiina ja Etelä-Afrikka) -maissa yli 50 vuoden ajanjaksolla. Kysymme, miten elinajanodote ja imeväiskuolleisuus sekä ekologinen jalanjälki ovat kehittyneet 33 maassa vuodesta 1960 vuoteen 2015? Olemme erityisesti kiinnostuneita siitä, onko löydettävissä maita, joissa kansanterveys on edistynyt samaan aikaan kun ekologinen jalanjälki on pienentynyt tai säilyttänyt kestävän tason. Aikaisemman tutkimuksen pohjalta oletamme, että ihmisten terveys ja ekologinen kestävyys eivät ole ajanjaksolla 1960-2015 olleet vääjäämättömässä ristiriidassa keskenään. Ennustamme löytävämme pienen ekologisen jalanjäljen maita, joissa elinikä on pidentynyt suhteellisesti enemmän, ja vastaavasti suuren ekologisen jalanjäljen maita, joissa elinikä on pidentynyt suhteellisesti vähemmän elinajanodotteen lähtötaso kontrolloituna. Vastaavasti suhteutamme ympäristön kestävyyden ja imeväiskuolleisuuden. Lisäksi pohdimme millaisia tekijöitä maiden välisten erojen ja ajallisten kehityskulkujen taustalla voisi vaikuttaa. 


\section{HYVINVOINTIVALTIOSTA YMPÄRISTÖVALTIOKSI?}

Maiden välisiä eroja terveyden ja ekologisen kuorman yhteydessä voi tarkastella niiden poliittishallinnollisella kyvyllä yhdistää hyvinvointi- ja ympäristöpolitiikka. Sekä kansanterveyden että ekologisen kestävyyden turvaamisen on ajateltu vaativan kansallisvaltioilta vahvaa kansallista sääntelyä, resurssien ja vastuun uudelleenjakoa, hallinnollisia rakenteita politiikan implementointiin, ja tiedon - niin terveyden edistämiseen, kuin ympäristöasioihin liittyvän - tuottamista ja tarjoamista [23]. Teoreettinen kirjallisuus esittää, että erityisesti hyvinvointivaltioissa, joissa edellä mainitut asiat toteutuvat varhain rakentuneen hallinnollisen ja poliittisen (demokraattisen) järjestelmän ansioista, ja joissa on hyvinvointia suosiva poliittinen ilmapiiri, on potentiaalia vaikuttaa sekä maan kansanterveyteen että ekologiseen kuormaan [24, 25, 26]. Hyvinvointivaltion rakenteiden, taloudellisen kehityksen ja sosiaalisen koheesion varaan on ajateltu olevan mahdollista rakentaa myös ns. ympäristövaltio [25, 27, 28].

Ympäristövaltiolle on useita englanninkielisiä vastineita, kuten ecological state, environmental state, green state, eco-state, eco-social state, eikä yhtä yhtenäistä määritelmää ole [23, 25, 29, 30, 31]. Suomalaisessa kirjallisuudessa on puhuttu lisäksi ekologisesta ja eko-sosiaalisesta hyvinvointivaltiosta [32]. Ilmo Massan [28] mukaan ympäristövaltio on hyvinvointivaltion rinnakkaiskäsite, jota voidaan käyttää niin teoreettisesti kuin empiirisesti. Yksinkertaistaen ympäristövaltio sisältää ajatuksen ekologisten ja hyvinvointitekijöiden yhtäaikaisesta huomioimisesta ja arvostamisesta politiikassa [23]. Ympäristövaltio on analoginen hyvinvointivaltiolle: Kun hyvinvointivaltio tarjoaa kansanlaisille sosiaalisia oikeuksia sosiaali- ja terveyspalveluihin sekä etuuksiin, joita pelkkä markkinajärjestelmä ei takaa, ympäristövaltion ajatellaan ottavan vastuuta ympäristöasioista, joita ei markkinoilla huomioida [23, 31].

Ympäristövaltion suhde talouskasvuun on kirjallisuuden valossa ristiriitainen. Kun Duit [23] toteaa ideaalin eko-valtion asettavan ympäristökysymykset talouskasvua tärkeämpään asemaan, on Gough [26] huolissaan tulevaisuusskenaariosta, jossa talouskasvu ei enää mahdollista (ympäristö)valtion toimintaa. Suomalainen ekososiaalinen hyvinvointivaltioajattelu puolestaan lähtee siitä, että talouskasvu on ekologisten kriisien juurisyy, ja näin ratkaistava ongelma itsessään [19]. Ympäristövaltiokirjallisuudessa viitataan usein myös ns. Kuznets-käyrään. Tämän hypoteesin mukaan valtioiden taloudellisen kehityksen alkuvaiheessa ympäristökuorma kasvaa, koska teollisuus on resurssi- ja energiainsentiivistä sekä käytetty teknologia kehittymätöntä. Lisäksi näissä maissa ympäristöpolitiikkaan panostamisen ajatellaan olevan toissijaista väestön hyvinvointiin nähden, eikä ympäristöpainotukselle ole myöskään kasvavan, poliittista muutosta usein edistävän, keskiluokan tukea. Sen sijaan myöhemmässä kehitysvaiheessa on myös ympäristöpolitiikka mahdollista väestön kohentuneen elintason ja poliittisen ilmapiirin muutoksen myötä. Hypoteesin mukaan tämä yhdessä kehittyneen teknologian kanssa kääntää talouskasvusta aiheutuvan ympäristökuorman laskuun [27]. Empiiriset tutkimukset ovat osoittaneet, että hypoteesi saattaa pitää paikkansa veden- ja ilmansaasteiden, mutta ei energiankulutuksen ja hiilidioksidipäästöjen kohdalla [26]. Myös Sommerer ja Lim [28] haastavat Kuznetsin käyrän osoittamalla, kuinka myös myöhemmin kehittyneet maat (uudet OECD - sekä BRIC -maat) ovat 1970-luvulta lähtien tehneet aktiivista ympäristöpolitiikkaa.

Myöskään muut teoreettiset esitykset ympäristövaltiosta ja sen perusteista eivät juuri saa tukea empiriasta. Tutkimus ei tue esimerkiksi sitä, että valtioiden panostaminen hyvinvointiin lisäisi automaattisesti myös aktiivista ympäristöpolitiikkaa [31]. Ympäristövaltioteorioissa on esitetty, että maan kuuluminen Esping-Andersenin [33] hyvinvointivaltiojaottelussa anteliaampiin, ns. sosiaalidemokraattisiin hyvinvointivaltioihin ennustaa vahvempaa ympäristöpolitiikkaa ja siten pienempää ekologista kuormaa verrattuna konservatiivisiin tai liberaaleihin hyvinvointivaltioihin, joissa hyvinvointipolitiikkakin on tiukempaa. Tämän tausta-ajatus on se, että hyvinvointia esimerkiksi verotuksella ja etuisuuksilla uudelleen jakanut kansa olisi valmiimpi ns. yhteisiin talkoisiin myös ympäristön hyväksi. Tutkijat ovat kuitenkin osoittaneet, että kuuluminen tiettyyn hyvinvointivaltiomalliin ei takaa ympäristöpolitiikan toteutumista [30, 23]. Demokraattisissa maissa kansan ajatellaan asettavan valtion vastuuseen niin terveyteen kuin ympäristöön liittyen, mutta empiiriset tulokset eivät yksiselitteisesti tue demokratiankaan yhteyttä ympä- 
ristöpolitiikkaan. Tulokset vaikuttavat riippuvan muun muassa demokratian operationalisoinnista [11, 34]. Konsensushakuinen politiikka, kuten kolmikantapolitiikka sekä hallituksen ja opposition pyrkiminen yhteistyöhön, voi erilaisten arvojen yhteensovittamisen vuoksi olla yhteydessä kestävään ympäristö- ja hyvinvointipolitiikkaan, mutta tässäkin on käytännössä eroja samankaltaiselta vaikuttavien maiden välillä [34].

Kansallisvaltioita on jaoteltu ympäristövaltioihin sen mukaan, miten niissä toteutetaan ympäristö- ja hyvinvointipolitiikkaa, tai miten ne sijoittuvat ekologisen kestävyyden ja hyvinvoinnin mittareilla mitattuna. Duit [23] tarkasteli 28 maan ympäristöön kohdistunutta sääntelyä, ympäristöverotusta, hallinnollista rakennetta (joka mahdollistaa politiikan implementaation) sekä ympäristötutkimukseen ja -kehittämiseen suunnattua rahoitusta. Hän tunnisti neljä ympäristövaltiota: vakiintuneen, nousevan, osittaisen ja heikon. Koch ja Fritz [30] erottelivat 30 maata sisältäneessä tutkimuksessaan ansioituneita, lukkiutuneita, vaarantuneita sekä epäonnistuneita ympäristövaltioita sen mukaan, miten maiden ympäristökuorma ja hyvinvointi kehittyivät vuodesta 1995 vuoteen 2010. Koska tutkijoiden luokittelukriteerit olivat erilaiset, saattoivat maat sijoittua näissä tutkimuksissa myös eri tavoin. Esimerkiksi Suomi oli Duitin [23] luokittelussa vakiintunut, mutta Kochin ja Fritzin [30] käyttämillä mittareilla epäonnistunut ympäristövaltio.

Tutkimukset osoittavat myös, kuinka ympäristövaltion kehitys ei ole välttämättä lineaarista niin, että aikaisemmat kehitysaskeleet jatkuisivat myös tulevaisuudessa [30, 23]. Vaikka monissa maissa, kuten esimerkiksi USA:ssa ja Japanissa, rakennettiin kestävän hyvinvointi- ja ympäristöpolitiikan mahdollistavia hallinnollisia ja poliittisia instituutiota jo 60- ja 70-luvulla, ovat nämä maat sijoittuneet 2010-luvulla ympäristövaltioluokitteluissa heikosti [23, 26]. Gough [26] pitää tähän keskeisenä syynä poliittisen ilmapiirin muutosta 1980-luvulla, jolloin globaali talousjärjestys liiketoiminnan ja politiikan kytköksineen alkoi näivettää hyvinvointivaltion ja ympäristövaltion perustaa monissa maissa. Toisen maailmansodan jälkeen rakentuneen modernin hyvinvointivaltion kehittyminen ympäristövaltioksi 2010-luvulla saattaakin olla tunnusomaista niille maille, joiden poliittinen ilmapiiri jatkui 1980-luvulla hyvinvointipolitiikalle suosiollisena.
Ympäristövaltioiden jaottelun empiirinen tutkimus antaa siis vaihtelevia tuloksia riippuen siitä, tarkastellaanko ympäristöpolitiikan toteuttamisen mahdollisuuksia vai lopputuloksia, ja miten nämä operationalisoidaan. Tutkimukset eivät myöskään tue ajatusta hyvinvointivaltion ja ympäristövaltion automaattisesta yhteydestä, lineaarisesta kehityksestä tai hyvinvointivaltioiden ylivoimaisuudesta ympäristöasioiden ratkaisijoina. Tästä on osoituksena esimerkiksi se, että OECD- ja BRICS -maiden ympäristöpolitiikat ovat lähentyneet toisiaan [27], mikä selittynee ainakin osittain kansainvälisillä sopimuksilla [25]. Myös EU-jäsenyys on samankaltaistanut ympäristöpolitiikkaa siihen kuuluvien maiden välillä [26].

Kaiken kaikkiaan niin korkean kuin alemmankin tulotason maissa ekologisen kuorman ja kansanterveyden kehityksen välinen yhteys on monimutkainen prosessi, jossa kietoutuu yhteen erilaisia sosiaalisia, poliittisia, historiallisia ja taloudellisia väliin tulevia tekijöitä [22]. Tässä tutkimuksessa esitellään ekologisen kuorman ja kansanterveyden yhtäaikaista kehitystä taustoiltaan hyvin erilaisissa valtioissa. Väliin tulevien tekijöiden moninaisuuden vuoksi yhteyksien tilastolliseen selittämiseen ei pyritä, vaan niitä pohditaan edellä kuvatun kirjallisuuden valossa.

\section{AINEISTO JA MENETELMÄT}

Tutkimusaineistomme koostuu 33 OECD- ja BRICS -maan aineistosta vuosilta 1960-2015, sisältäen tiedot maiden ekologisesta jalanjäljestä, imeväiskuolleisuudesta ja elinajanodotteesta kyseiseltä ajanjaksolta. OECD, eli Taloudellisen yhteistyön ja kehityksen järjestö, perustettiin Euroopan ja Pohjois-Amerikan valtioiden toimesta kehittämään jäsenmaidensa talouskasvua ja vapaakauppaa. Nykyisistä 36 OECD -maasta jätimme aineiston ulkopuolelle seitsemän maata puuttuvien havaintojen vuoksi (Islanti, Latvia, Liettua, Slovakia, Slovenia, Tšekki, Viro), sekä Luxemburgin väkiluvun pienuuden vuoksi.

BRICS -mailla tarkoitetaan puolestaan 2000luvun vahvan talouskasvun sekä suuren väkiluvun leimaamaa maaryhmää, johon kuuluu Brasilia, Venäjä, Intia, Kiina ja Etelä-Afrikka. Yhdessä OECD- ja BRICS -maat kattavat noin 60 prosenttia maailman väestöstä ja ovat taloudellisilla osoittimilla kaikkein vauraimmat sekä nopeimmin kehittyvät maat maailmassa. OECD -maat 
pitävät nykyisellään kärkisijoja monien kansanterveyden osoittimien suhteen, kun taas BRICS -maiden kansanterveys on viime vuosikymmeninä kohentunut merkittävästi [1].

Aineistoon on koottu vuosittaiset tiedot maiden ekologisesta jalanjäljestä asukasta kohti Ecological Footprint -verkoston aineistopankista. Ekologinen jalanjälki on paljon ja erilaisissa yhteyksissä, kuten tutkimuksissa, käytetty mittari kuvaamaan yksilöiden ja alueiden ekologista kuormaa. EF kuvaa kunkin ihmisen kuluttaman ravinnon, materiaalien ja energian tuottamisesta sekä kuluttamisesta syntyneiden jätteiden (esim. hiilidioksidipäästöjen) käsittelystä maaja vesialueille syntyvää ekologista kuormaa. Se sisältää tiedot energiankulutuksesta, asumisesta, maa-alueiden käytöstä, ruoantuotannosta ja kalastuksesta, ja se esitetään usein globaalihehtaareina (gha), joka on suhteutettu maapallon tuottavana pidettäviin maa- ja vesialueisiin. [35.]

Kansanterveyden osoittimina tässä tutkimuksessa käytetään elinajanodotetta ja imeväiskuolleisuutta. Vastasyntyneen elinajanodote tarkoittaa ajanjaksoa, jonka tiettyyn maahan tietyllä hetkellä syntynyt lapsi voi odottaa keskimäärin elävänsä. Maakohtaiset elinajanodotteet on poimittu Maailmanpankin aineistopankista. Imeväiskuolleisuus taas tarkoittaa ensimmäisen elinvuotensa aikana kuolleiden lasten osuutta kaikista elävänä syntyneistä. Maakohtaiset imeväiskuolleisuusluvut poimittiin YK:n organisaatioiden välisen lapsikuolleisuustyöryhmän [36] tietokannasta.

Tutkimus on kuvaileva. Ensimmäistä analyysia varten laskimme kaikille 33 maalle ekologinen jalanjälki per asukas -vuosikeskiarvon vuosilta 1961-2014. Tämä vuosikeskiarvo indikoi kunkin maan ekologista kuormaa 53 vuoden tutkimusjakson ajalta. Molempien kansanterveyden osoittimien kohdalla kiinnostuksemme kohdistui maakohtaiseen muutokseen, jonka analysoimiseen käytettiin lähtötasoa vuodelta 1960 ja päätepistettä vuonna 2015. Erilaisten lähtökohtien ja kehityspotentiaalien vuoksi maita ei ollut kuitenkaan mielekästä vertailla absoluuttisten kasvulukujen pohjalta, vaan kansanterveyden lähtötaso tuli molempien osoittimien kohdalla jollain tavoin huomioida. Elinajanodotteen kohdalla päädyimme laskemaan tutkimusjaksolla tapahtuneen kasvun suhteessa teoreettiseen sa- dan vuoden maksimiin ja ilmaisimme tuloksen prosentteina:

(elinajanodote 2015 - elinajanodote 1960) / (100 - elinajanodote 1960) $x 100$

Imeväiskuolleisuuden kohdalla laskimme vastaavasti tutkimusjaksolla tapahtuneen alenemisen suhteessa imeväiskuolleisuuden nollatasoon ja ilmaisimme tuloksen prosentteina:

(imeväiskuolleisuus 1960-imeväiskuolleisuus 2015) / (imeväiskuolleisuus 1960) x 100

Esittelemme saamamme tulokset hajontakuvioina. Kaikissa hajontakuvioissa $\mathrm{x}$-akselille on sijoitettu ekologisen jalanjäljen vuosikeskiarvo ja y-akselille toinen kansanterveyden edistymistä kuvaavista osoittimista. Kuvioissa 1 ja 2 on mukana kaikki 33 maata omina havaintoyksikköinään. Kuvioissa 3 ja 4 havaintoyksikköinä tarkastellaan yksittäisten maiden sijaan viittä kehitykseltään erilaista aluetta, joiden väestömäärä on suuri, ja jotka edustavat eri maanosia (Eurooppa, Pohjois-Amerikka, Latinalainen Amerikka, Intia ja Kiina). Tämän tiivistämisen perusteena olivat empiiriset havainnot kuvioista 1 ja 2 (ks. tulososa). Tutkimusjakso on kuvioissa 3 ja 4 jaettu kolmeen erilliseen ajankohtaan. Viidelle tarkasteltavalle alueelle laskettiin ekologisen jalanjäljen vuosikeskiarvo vuosilta 1961-1965, 1986-1990 ja 2010-2014. Jokaista viiden vuoden aikapistettä ennakoivat ja sitä seuraavat terveyden indikaattorit laskettiin samaan tapaan kuin yksittäisille maille koko ajanjakson kohdalla (Kiinan imeväiskuolleisuustietoja 1960-luvulta ei ollut saatavissa). Näin oli mahdollista tarkastella ajallisia muutoksia ekologisen jalanjäljen ja kansanterveyden edistymisen välisessä suhteessa.

\section{TULOKSET}

Kuviot 1 ja 2 osoittavat, että maakohtainen ero pienimmän ja suurimman ekologisen jalanjäljen välillä on tarkastellulla 53 vuoden ajanjaksolla yli kymmenkertainen. Elinajanodotteen suhteellisessa edistymisessä maiden välillä on suurempia eroja kuin imeväiskuolleisuuden edistymisessä. Elinajanodotteen suhteellinen kasvu ja imeväiskuolleisuuden suhteellinen edistyminen on ollut huomattavinta maissa, joissa ekologinen kuorma on ollut keskimääräistä pienempi. 


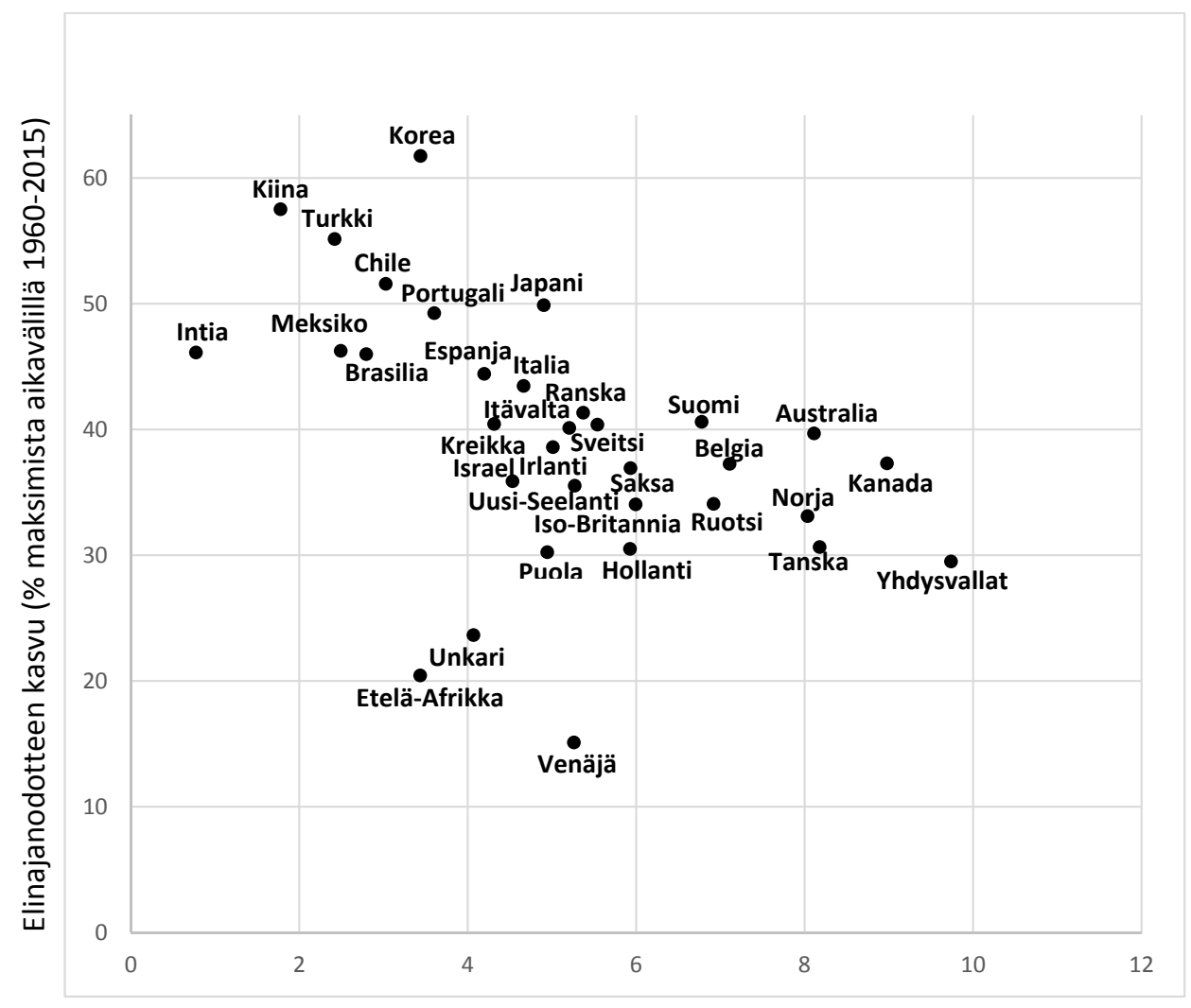

Ekologinen jalanjälki* (vuosikeskiarvo ajalta 1961-2014)

*Israelin ekologinen jalanjälki alkaa vuodesta 1961.

Kuvio 1. Ekologinen jalanjälki ja elinajanodotteen kasvu

Erot ekologisen jalanjäljen ja kansanterveyden edistymisen välisessä suhteessa ovat maiden välillä huomattavia. Yhdysvallat on kuormittanut ympäristöä tarkastelujoukossa eniten, mutta sen saavutukset ovat neljän heikoimman maan joukossa molemmilla kansanterveysmittareilla. Suomi kuormittaa ympäristöä keskivertoa enemmän, mutta saavuttaa myös keskivertoa parempia terveystuloksia. Maltillisen ekologisen kuorman Etelä-Afrikka ei ole onnistunut elinajanodotteen edistämisessä eikä imeväiskuolleisuuden vähentämisessä. Myöskään Venäjä, jonka ekologinen kuorma on ollut ajanjaksolla maiden keskitasoa, ei ole saavuttanut hyviä tuloksia elinajanodotteessa. Sen sijaan Korea on menestynyt erinomaisesti molemmilla valituilla kansanterveyden indikaattoreilla mitattuna maan ekologisen jalanjäljen jäädessä keskivertoa pienemmäksi. Intia ja Kiina ovat ainoita maita, joissa ekologisen jalanjäljen vuosikeskiarvo on koko tarkastelujaksolla mitattuna kestäväksi arvioidulla tasolla (alle 1,7 gha). Tämän lisäksi näissä maissa on 53 vuoden aikana otettu huomattavia kansanterveyden edistysaskeleita.

Euroopan maat, riippumatta niiden ilmastovyöhykkeestä tai hyvinvointivaltioiden anteliaisuudesta, muodostavat varsin yhtenäisen ryppään hajontakuvioissa 1 ja 2. Myös Kanadan ja Yhdysvaltojen terveyden edistymisen ja ekologisen jalanjäljen kehitys on keskenään samansuuntaista. Latinalaisen Amerikan maat, huolimatta ovatko OECD- vai BRICS -maita, ovat niin ikään lähellä toisiaan hajontakuviossa. Näiden havaintojen perusteella tarkastellaan Eurooppaa, Pohjois-Amerikkaa ja Latinalaista Amerikkaa omina havaintoyksikköinään hajontakuvoissa 3 ja 4, jossa tulee näkyviin alueiden kansanterveyden ja ekologisen jalanjäljen ajallinen kehitys. 


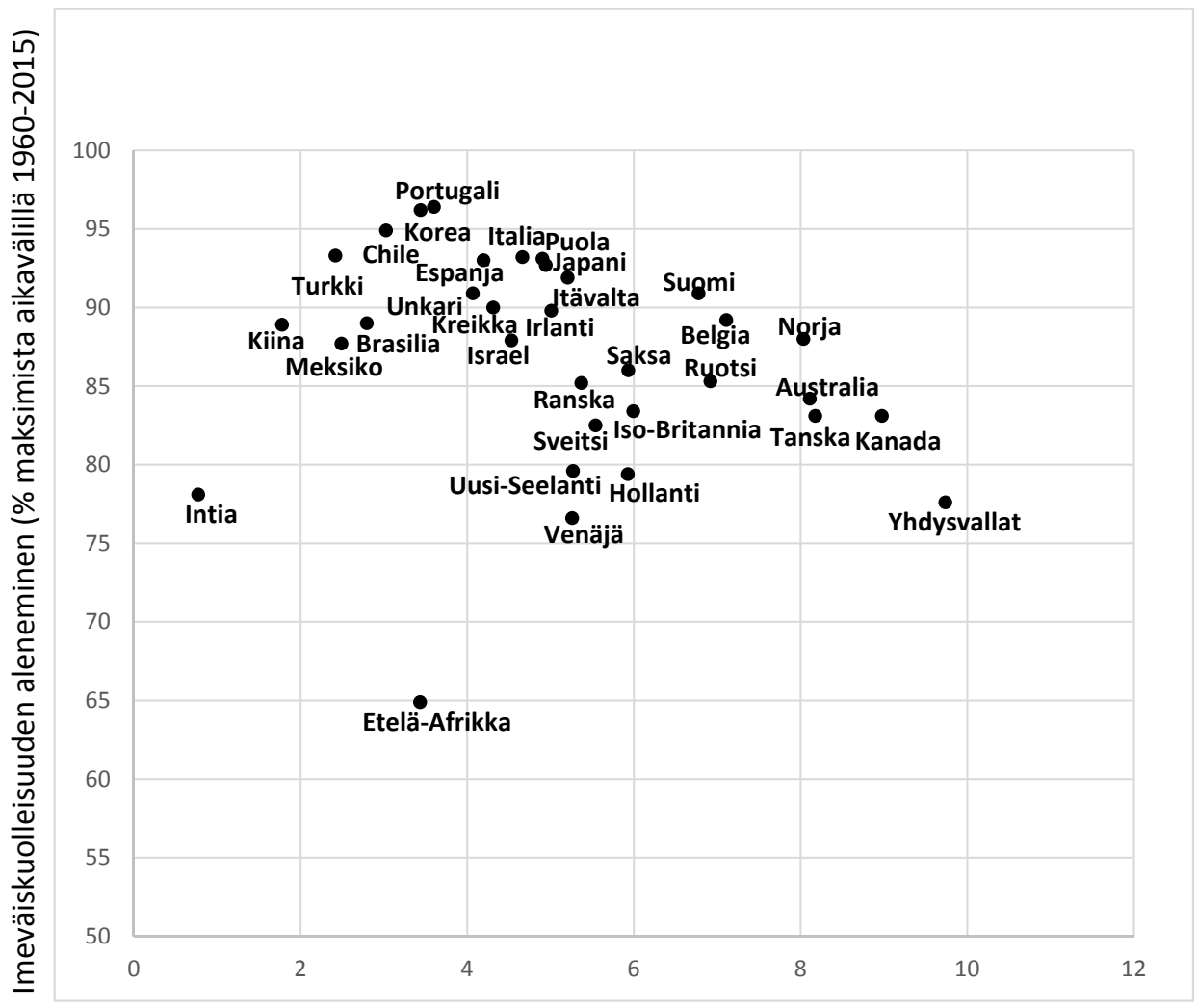

Ekologinen jalanjälki (vuosikeskiarvo ajalta 1961-2014)

*Saksan imeväiskuollleisuus alkaa vuodesta 1968, Israelin vuodesta 1974, Etelä-Afrikan
vuodesta 1974, Kiinan vuodesta 1969, Venäjän vuodesta 1970

Kuvio 2. Ekologinen jalanjälki ja imeväiskuolleisuuden aleneminen

Maantieteellisen kattavuuden varmistamiseksi jatkotarkasteluun otettiin mukaan myös Kiina ja Intia, jotka pidettiin omina yksiköinään niiden suuren väestömäärän vuoksi. Intia ja Kiina eroavat muista valituista alueista niiden pienen ekologisen kuorman ja samanaikaisen kansanterveyden kehityksen puolesta. Tulososion jatkossa keskitymme ajallisiin kehityskulkuihin näillä viidellä alueella, mutta liitetaulukossa 1 esitellään ajallisen kehityksen tunnusluvut kaikkien 33 maan osalta.

Euroopan, Pohjois-Amerikan ja Latinalaisen Amerikan kansanterveyden ja ekologisen jalanjäljen välisen suhteen muutokset 60-luvun, 80-luvun lopun sekä 2010-luvun välillä ovat olleet kohtuullisen pieniä (Kuviot 3 ja 4). Ekologisessa kuormassa ne ovat kaikkina kolmena ajankohtana keskenään eri tasoilla, ts. kunkin ekologinen jalanjälki on muuttunut ajanjaksolla verrattain vähän ja keskinäiset erot ovat säilyneet. Kolmen eri ajankohdan väliset erot elinajanodotteen suhteellisessa kasvussa olivat niin ikään pieniä (Kuvio 3), kun taas imeväiskuolleisuuden suhteellinen aleneminen vaihteli hieman enemmän (Kuvio 4). Intian ekologisen jalanjäljen kasvu oli pienintä, mutta edistysaskeleet imeväiskuolleisuuden alenemisessa olivat alueista toiseksi suurimmat (Kuvio 4).

Kiinassa sekä kansanterveyden suhteellisen edistymisen, että ekologisen kuorman siirtymät ovat olleet tarkastelluista alueista suurimpia. Yhtäältä, 1960-luvulla matalan ekologisen kuorman Kiinassa elinaika piteni vauhdilla verrattuna myöhempiin ajanjaksoihin, jolloin Kiinan suhteellinen elinajanodotteen kasvu on ollut muiden alueiden tasolla, ja ekologinen jalanjälki lähellä 


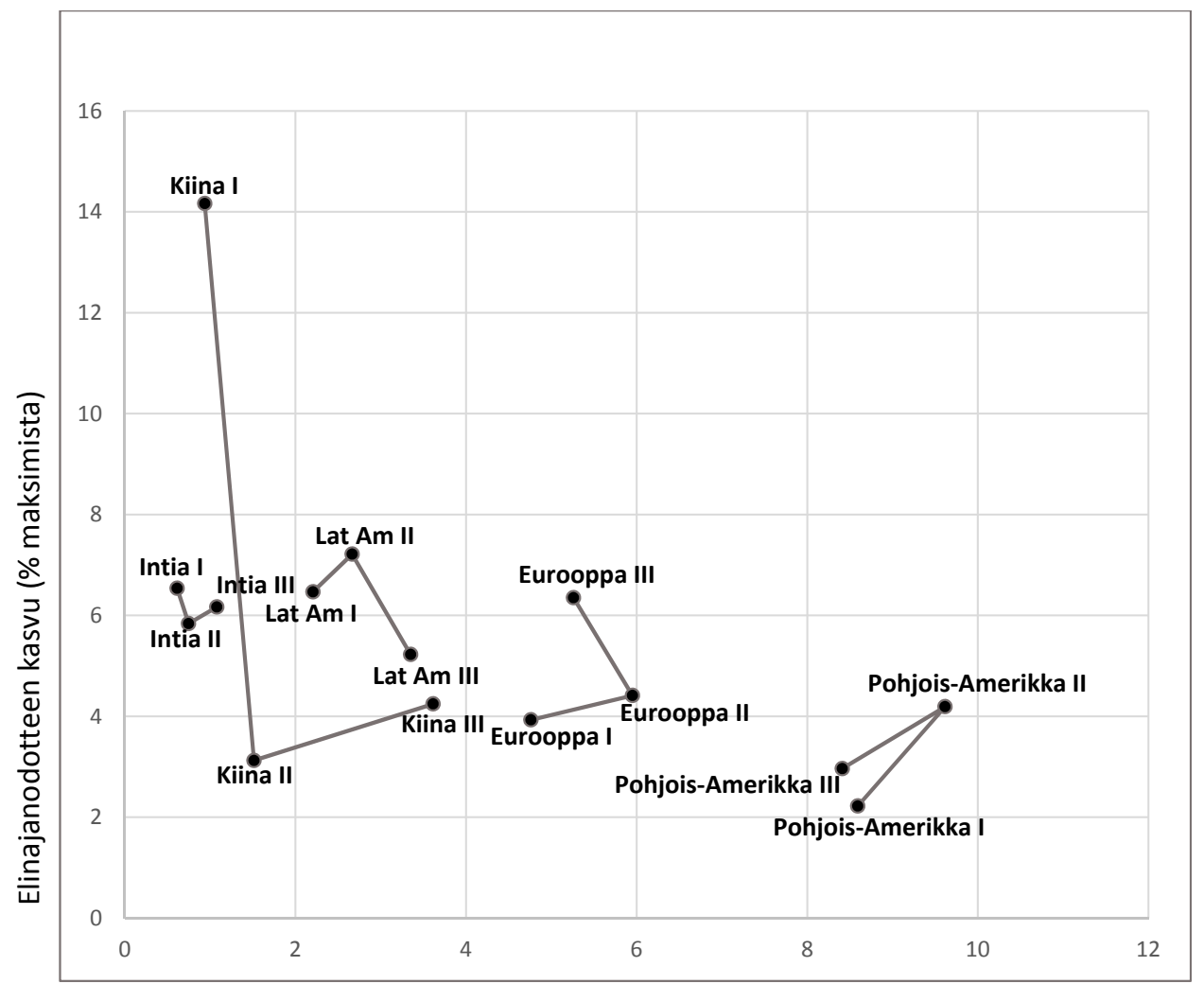

Ekologinen jalanjälki (vuosikeskiarvo)

* Ajankohdassa I ekologinen jalanjälki vuosina 1961-1965 ja elinajanodote vuosilta 1960 sekä 1966, ajankohdassa II ekologinen jalanjälki vuosina 1986-1990 ja elinajanodote vuosilta 1985 sekä 1991, ajankohdassa III ekologinen jalanjälki vuosina 2010-2014 ja elinajanodote vuosilta 2009 sekä 2015.

Kuvio 3. Ekologinen jalanjälki ja elinajanodotteen kasvu kolmena eri ajankohtana

Euroopan tasoa (Kuvio 3). Toisaalta, 2010-luvun Kiinassa imeväiskuolleisuus aleni tuntuvasti verrattuna 1980-luvun loppupuoliskoon, jolloin suhteellinen imeväiskuolleisuuden aleneminen oli tarkastelluista alueista heikointa juuri Kiinassa (Kuvio 4).

Eurooppa ja Pohjois-Amerikka ovat onnistuneet alentamaan ekologista kuormaansa 1980luvulta 2010-luvulle. Samaan aikaan Euroopassa suhteellinen elinajanodotteen kasvu on ollut 2010-luvun ajanjaksona korkeinta tarkastelluilla alueilla, ja kehittynyt aikaisemmista aikapisteistä positiivisesti. Pohjois-Amerikassa elinajanodotteen kasvu teoreettisesta maksimista sitä vastoin laski 1980-luvun ja 2010-luvun välillä (Kuvio 3). Molemmilla näillä alueilla alle 1-vuotiaiden eloonjäämisen suhteellinen edistyminen laski 2010-luvulla verrattuna 1960- ja 1980-lukuun (Kuvio 4).

Intian kehityskulut osoittavat, että imeväiskuolleisuutta on mahdollista alentaa ja elinajanodotetta parantaa kestävän ekologisen jalanjäljen oloissa, ja jopa merkittävämmin kuin korkeamman ekologisen jalanjäljen alueilla Pohjois-Amerikassa ja Euroopassa. Viidestä alueesta neljässä ekologinen jalanjälki kasvoi samaan aikaan kansanterveyden edistymisen kanssa. Eurooppa oli ainoa alue, missä kansanterveys lisääntyi samalla kun ekologinen kuorma pieneni. Intia oli alueista ainoa, jonka ekologinen jalanjälki oli sen kasvusta huolimatta vielä 2010-luvullakin kestävällä tasolla. 


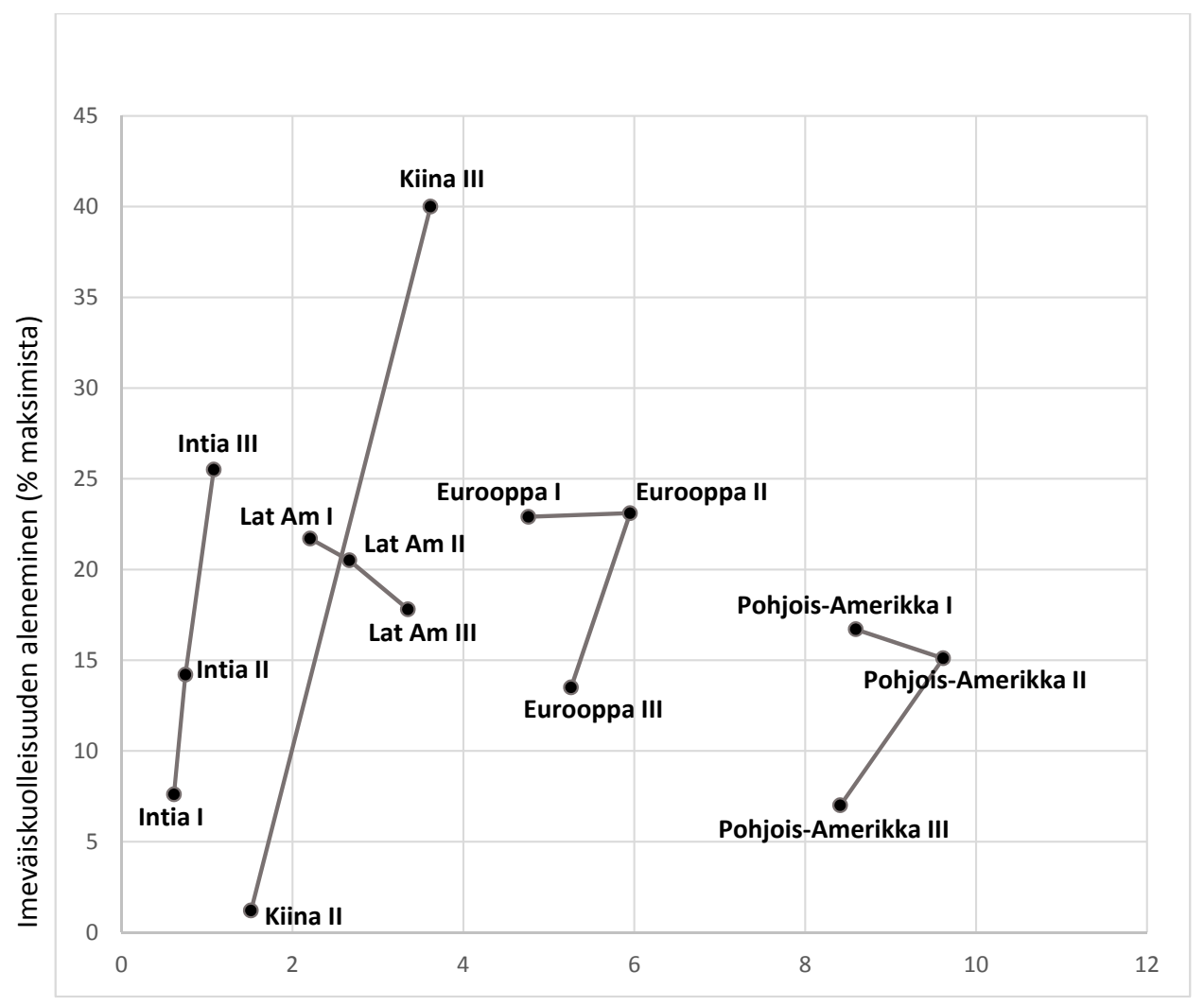

Ekologinen jalanjälki (vuosikeskiarvo)

* Ajankohdassa I ekologinen jalanjälki vuosina 1961-1965 ja imeväiskuolleisuus vuosilta 1960 sek. 1966, ajankohdassa II ekologinen jalanjälki vuosina 1986-1990 ja imeväiskuolleisuus vuosilta 1985 sek: 1991, ajankohdassa III ekologinen jalanjälki vuosina 2010-2014 ja imeväiskuolleisuus vuosilta 2009 sek 2015.

Kuvio 4. Ekologinen jalanjälki ja imeväiskuolleisuuden aleneminen kolmena eri ajankohtana

\section{POHDINTA}

Andy Haines esitti 20 vuotta sitten kysymyksen, tarkoittaako kansanterveyden edistäminen väistämättä ekologisen kuorman kasvua [7]. Tutkimuksemme vastaa tähän, ja osoittaa, että ihmisten terveyden edistyminen on viimeisten yli 50 vuoden aikana ollut mahdollista myös kestävän tai pienen ekologisen jalanjäljen oloissa. Sekä elinajanodote että imeväiskuolleisuus saattoivat kehittyä positiiviseen suuntaan, vaikka maan ekologinen jalanjälki oli kestävällä tasolla tai pieneni.

Tulokset osoittavat aikaisempien tutkimusten tapaan $[8,7,21]$, että suurin positiivinen kehitys kansanterveydessä saatiin pienen ekologisen kuorman maissa, erityisesti 1980-luvulla. Toisaalta käänteisesti, sekä taloudellisesti kehittyneissä että kehittyvissä maissa kansanterveyden kehitys saattoi olla heikkoa suuresta ekologisesta jalanjäljestä huolimatta. Jorgenson ja Dietz [21] esittivät osin samojen maiden vertailussa, kuinka talouskasvu kehittyneissä maissa tuotti vielä 1970-luvulla kansanterveyttä kohtalaisella ekologisella jalanjäljellä, kun taas 1980-luvun jälkeen talouskasvusta saatu kansanterveyden hyöty vaati vuoteen 2003 asti suuren ekologisen jalanjäljen [21]. Toisin sanoen talouskasvu ei ole taannut kansanterveyden positiivista kehitystä, mutta se on lisännyt ekologista kuormaa [21].

Verrattuna aikaisempiin tutkimuksiin tämän 
tutkimuksen pidempi seuranta-aika sekä aikapisteiden ja alueiden erillinen tarkastelu antavat aihetta myös positiivisempaan tulkintaan ekologisen kuorman ja kansanterveyden kehityksen suunnasta. Euroopassa ekologinen jalanjälki pieneni 1980-luvulta 2010-luvulle ja samaan aikaan suhteellinen elinajanodote lisääntyi muita alueita selvemmin. Myös Pohjois-Amerikassa ekologinen jalanjälki pieneni, mutta samanaikaiset kansanterveyden edistysaskeleet olivat suhteellisesti verrattuna vaatimattomammat kuin millään muulla alueella. Vaikka ekologinen jalanjälki on Euroopassa ja Pohjois-Amerikassa edelleen kestämättömällä tasolla, on suunta oikea. Intiassa ekologisen jalanjäljen kasvu 1960-luvulta 2010-luvulle oli hyvin pientä, mutta elinajanodotteen kasvu merkittävää. Yhdessä nämä tulokset antavat viitteitä siitä, että kansanterveyden taso voidaan tulevaisuudessa säilyttää ja terveyttä edistää ilman että luonnonvarojen kulutus lisääntyy. Tähän lopputulemaan päätyvät myös Fanning ja O'neill [37] tutkittuaan bruttokansantuotteen ja hiilijalanjäljen sekä elinajanodotteen yhteyttä 120 maassa vuosina 2005-2015.

Kansallisen hyvinvointipolitiikan ja ympäristöpolitiikan yhteyksistä on esitetty erilaisia teorioita. Esimerkiksi mailla, joissa on jo varhain luotu suotuisat poliittiset, hallinnolliset ja rakenteelliset olosuhteet kansan hyvinvoinnin edistämiselle, on ajateltu olevan mahdollisuus tehdä myös vaikuttavampaa ympäristöpolitiikkaa [31, $27,30]$. Tämän tutkimuksen tulosten voi ajatella tukevan toisaalta hyvinvointi- ja ympäristövaltion synergiaa [30]. Esimerkiksi Euroopan myönteistä suuntaa molemmissa ulottuvuuksissa voi selittää alueen maiden historia hyvinvointivaltioina ja samanaikainen sitoutuminen kansainväliseen, erityisesti EU:n ympäristöpolitiikkaan [26]. Toisaalta, kehittyvillä alueilla saavutettiin merkittäviä kansanterveyden edistysaskeleita, ja erityisesti Intiassa samanaikainen muutos ekologisessa jalanjäljessä oli pientä, eikä ylittänyt kestäväksi määriteltyä 1,7 gha tasoa koko seurantajakson aikana. Tämä antaa viitteitä, että myös alemman tulotason maissa on mahdollista yhdistää hyvinvointi- ja ympäristöpolitiikka [27].

Aikaisemmissa tutkimuksissa vain Rainham ym. [12, 20] ovat tarkastelleet elinajanodotteen lisäksi imeväiskuolleisuutta terveyden indikaattorina. Rainhamin ym. [12] tutkimuksessa käy- tettiin 152 maan tietoja vuodelta 1996, ja tuloksena oli, että korkea imeväiskuolleisuus korreloi voimakkaasti matalan ekologisen jalanjäljen kanssa. Tutkijat toteavatkin, että kansanterveyden kehittäminen on yhteydessä kestämättömään ekologiseen kehitykseen. Meidän tuloksemme 2010-luvun kehityksestä antavat lohdullisemman kuvan, tosin tutkittuja maita on huomattavasti vähemmän. Imeväiskuolleisuuden aleneminen erityisesti 2010-luvun Kiinassa voi myös olla maailmanlaajuisesti tarkastellen poikkeus. Esimerkiksi sukupuolen määrittämisen mahdollistavan sikiödiagnostiikan lisääntyminen poikalapsia suosivassa Kiinassa voi selittää osaltaan sitä, että 2010-luvun Kiinassa suhteellinen imeväiskuolleisuus aleni tuntuvasti verrattuna 1980-luvun loppupuoliskoon. Myös asteittainen luopuminen yhden lapsen politiikasta on voinut vaikuttaa imeväiskuolleisuuden alentumiseen Kiinassa [38]. Kansallisten hyvinvointipolitiikoiden (esimerkiksi terveyspalveluiden ja sosiaalietuuksien) toteuttamisen onkin todettu vaikuttavan imeväiskuolleisuuteen vahvasti [39], erityisesti köyhissä ja keskituloisissa maissa [40, 41, 42].

Tutkimuksemme keskeisiä vahvuuksia ovat käyttämämme objektiiviset kansanterveyden ja ekologisen hinnan osoittimet, pitkä tutkimusjakso sekä vertaileva asetelma. Ekologinen jalanjälki on luotettavin ja paljon tutkimuksissa käytetty mittari kuvaamaan yksilöiden ja alueiden ekologista kuormaa. Elinajanodote ja imeväiskuolleisuus taas ovat sekä kovimmat että tarkimmat kansanterveyden osoittimet. Hyödynsimme koko ekologisen jalanjäljen mittaushistorian vuosilta 1961-2014. Otimme vertailevaan asetelmaan mukaan OECD- ja BRICS -maat, jolloin mukaan tulivat vauraimmat ja nopeimman talouskasvun maat, suurimman ekologisen jalanjäljen ja oletettavasti nopeimmin kasvavan ekologisen jalanjäljen maat sekä korkeimman elinajanodotteen ja pienimmän imeväiskuolleisuuden maat. OECDja BRICS -maiden kohdalla puuttuvia havaintoja oli käyttämissämme aineistoissa myös huomattavasti vähemmän kuin tutkimuksen ulkopuolelle jätettyjen (noin 40 prosenttia maailman väestöstä kattavien) maiden kohdalla.

Johtopäätöksiä tehdessä on hyvä huomioida joitain tutkimukseemme liittyviä rajoitteita. Ensinnäkin, vaikka ekologinen jalanjälki on paras 
käytössä oleva mittari kokonaisvaltaisen ekologisen kuorman vertailuun maiden välillä, on silti mahdollista, että se aliarvioi joidenkin maiden ekologista kuormaa ja korostaa toisten. Ekologista kuormaa on vaikea laskea ns. "näkymättömän kulutuksen” vuoksi, mikä tarkoittaa sitä, että teollisuusmaiden asukkaiden kulutuksesta aiheutuvat vaikutukset on ulkoistettu kehittyviin maihin. Ekologiseen jalanjälkeen lasketaan myös tämä ulkoistettu ympäristökuorma, mutta ero maiden välillä voi todellisuudessa olla suurempi. [42.]

Ekologisessa jalanjäljessä on iso ero varakkaiden ja vähävaraisten väestöryhmien kesken maiden sisällä. Esimerkiksi Suomessa vuonna 2016 rikkaimpaan tulokymmenykseen kuuluvien henkilöiden kulutus aiheutti noin 2,6 kertaa enemmän päästöjä ja vei lähes 3 kertaa enemmän raaka-ainevaroja kuin köyhimmän kymmenyksen kulutus [44]. Myös elinajanodotteessa ja imeväiskuolleisuudessa on huomattavia eroja maiden sisällä. Esimerkiksi Intiassa oli imeväiskuolleisuudessa lähes 5-kertainen ero eri osavaltioiden välillä vuosina 2005-2006 [45]. Tässä tutkimuksessa ei ole otettu huomioon maiden sisäistä vaihtelua ekologisessa jalanjäljessä ja kansanterveydessä mikä olisikin kiinnostava jatkotutkimusaihe.

Toiseksi, emme tässä tutkimuksessa vakioineet tekijöitä, joilla saattaa olla vaikutusta sekä kansanterveyteen että ekologiseen kuormaan, kuten bruttokansantuotetta, ilmastovyöhykettä tai kaupungistumisastetta [21]. Kolmanneksi, suurin elinajanodotteen suhteellinen kasvu, kuten myös suurin imeväiskuolleisuuden suhteellinen väheneminen, tapahtui pienen ekologisen kuormituksen maissa. Kyseisissä myöhään teollistuneissa maissa kansanterveyden lähtötaso oli erittäin alhainen verrattuna aiemmin teollistuneisiin maihin. Analyysissamme huomioitiin maiden väliset erot terveysindikaattoreiden lähtötasossa parhaalla löytämällämme tavalla. Saamiamme tuloksia voi tästä huolimatta osittain selittää parantamisen vaikeus siellä, missä asiat olivat jo verrattain hyvin, ja parantamisen helppous siellä, missä asiat olivat lähtökohtaisesti huonosti.

\section{JOHTOPÄ̈̈TÖKSET}

Tämän tutkimuksen tulokset antavat viitteitä siitä, että kansanterveyden taso voidaan säilyttää ja terveyttä edistää vähäisemmän resurssien käytön ja niukemman kulutuksen oloissa. Toivoa antaa erityisesti se, että korkeamman tulotason maissa ekologinen kuorma pieneni 2010-luvulle tultaessa, ja samalla niissä otettiin edelleen kehitysaskeleita kansanterveydessä. Huolestuttavaa puolestaan on, että väkirikkaissa alemman tulotason maissa lähestytään ekologisessa kuormassa korkean tulotason maita. Intiassa ekologisen kuorman kasvuvauhti on ollut arvostettavan hidasta, mutta Kiinassa huolestuttavan nopeaa. Kaiken kaikkiaan sekä hyvinvointivaltioissa että alemman tulotason maissa on molemmissa potentiaalia ympäristövaltioiksi, joissa sekä ympäristö että väestön terveys asetetaan keskiöön.

\section{RAHOITTAJAT:}

Tutkimusta ei ole rahoittanut mikään taho.

\section{KIRJOITTAJIEN KONTRIBUUTIOT:}

Pulkki on koonnut aineistoon ekologisen jalanjälki -muuttujat, koonnut taustakirjallisuuden ja kirjoittanut taustan ensimmäisen version, muokannut tuloksia, kirjoittanut pohdintaa, sekä viimeistellyt tekstin.

Perkiö on koonnut aineistoon imeväiskuolleisuus -muuttujat, kirjoittanut auki tuloksia ja pohdintaa, sekä kommentoinut taustaa.

Kokkinen on koonnut aineistoon elinajanodote -muuttujat ja tehnyt analyysit ja kuviot, kirjoittanut auki tuloksia ja pohdintaa, sekä muokannut taustaa.

Kaikki kirjoittajat ovat nähneet ja hyväksyneet viimeisen version. 
Humanity has made significant advances in health worldwide. However, at the same time, as human health has improved, the Earth's ecosystems have fallen into crisis. We analyze the development of public health and the ecological burden in OECD and BRICS for over 50 years. The article explores how have public health and ecological footprint developed in 33 countries from 1960 to 2015. We aimed to find countries where both public health and ecological footprint have developed positively. We discuss the results in light of the environmental state literature.

The panel data included information on the countries' ecological footprint, infant mortality, and life expectancy from the years 1960-2015 for 33 countries. For each country, the ecological footprint was calculated as an annual average. Public health indicators were analyzed between 1960 and 2015. As the baseline levels of public health and thus, development potential varied between countries, absolute development was correlated with maximum theoretical develop- ment. After country-specific analyzes, countries were grouped into larger areas for more detailed temporal analysis. The results are presented as scatter patterns.

We found countries with a sustainable or diminishing ecological footprint and relatively high levels of public health, and countries with a large ecological footprint, but little development in public health. The results suggest that a good level of public health can be maintained, and health promoted in conditions of reduced ecological burden. Both welfare states and later developed countries have the potential to be environmental states that take care of both the environment and the health of the population.

Keywords: public health, ecological footprint, life expectancy, infant mortality, environmental state

Saapunut 13.06.2019

Hyväksytty 23.10.2019

\section{LÄHTEET}

(1) WHO. BRICS Health and WHO. Country Presence Profile. 2017. Luettu 30.3.2019. https://apps.who.int/iris/bitstream/ handle/10665/255800/ WHO-CCU17.05-eng.pdf; jsessionid $=36379763 \mathrm{~A} 5$ C07828F0C801E9AF960C6D? sequence $=1$

(2) OECD. Health at a glance 2017. OECD indicators. OECD Publishing, Paris. 2018. Luettu 30.3.2019. https://doi.org/10.1787/health_glance-2017-en

(3) Raleigh V. Trends in life expectancy in EU and other OECD countries: Why are improvements slowing? OECD Health Working Paper No. 108. 2019. Luettu 25.5.2019.

https:/www.oecd-ilibrary.org/

docserver/ 223159ab-en.

df?expires $=1555325927 \&$ id $=$ id $\&$ accname $=$ guest \&checksum= F55B28CE7575816365A1DEADADF799C2

(4) Rayner G, Lang T. Ecological Public Health. Reshaping the conditions of good health. Routledge. 2012. https://doi.org/10.4324/9780203134801

(5) Frenk J. Health and the economy: A vital relationship. OECD. 2004. Luettu 25.5.2019 http://oecdobserver.org/news/archivestory.php/ aid/1241/Health_and_the_economy:_A_vital_ relationship_.html

(6) WHO. 13th General Program of Work (GPW13). 2018. Luettu 30.3.2019. https:// www.who.int/about/what-we-do/gpw-thirteenconsultation/en/ p. 4.

(7) Haines A. Sustainable energy, economic growth and public health. MCS 2000;17:56-62. https://doi.org/10.1080/13623690108409555

(8) McMichael AJ, Powles JW. Human numbers, environment, sustainability, and health. BMJ 1999;319:977-980. https://doi.org/10.1136/bmj.319.7215.977

(9) McMichael AJ, Butler CD. Promoting global population health while constraining the environmental footprint. Annu Rev Publ Health 2011;32:179-197. https://doi.org/10.1146/annurevpublhealth-031210-101203

(10) Joutsenvirta M, Hirvilammi T, Ulvila M, ym. Talous kasvun jälkeen. Tallinna: Gaudeamus; 2016

(11) Knight K, Rosa E. The environmental efficiency of well-being: A cross-national analysis. Soc Sci Res 2011;40:931-949. https://doi.org/10.1016/j.ssresearch.2010.11.002

(12) Rainham D, McDowell I. The sustainability of population health. Popul Environ 2005;26:303324. https://doi.org/10.1007/s11111-005-3344-9 
(13) Whitmee S, Haines A, Breyrer C, ym. Safeguarding human health in the Anhtropocene epoch: report of The Rockefeller FoundationLancet Commission on planetary health. Lancet 2015;386:1973-2028.

https://doi.org/10.1016/S0140-6736(15)60901-1

(14) Haines A. Addressing challenges to human health in the Anthropocene epoch - an overview of the findings of the Rockefeller/Lancet Commission on Planetary health. Int Health 2017;9:269-274. https://doi.org/10.1093/inthealth/ihx036

(15) Haines A. Challenges for health in the Anthropocene epoch. BMJ 2019;364:I460. https://doi.org/10.1136/bmj.1460

(16) WWF. Living Planet Report - 2018: Aiming higher. Luettu 30.8.2019. https://www.wwf. org.uk/sites/default/files/2018-10/LPR2018_ Full\%20Report.pdf

(17) O’Neill D. A Good Life For All Within Planetary Boundaries. Luettu 15.9.2019. https:/goodlife.leeds.ac.uk/countries/\#Finland

(18) Ecological footprint - Global Footprint Network. Luettu 15.9.2019. https://www. footprintnetwork.org/our-work/sustainabledevelopment/

(19) Salonen A. Ekososiaalinen paradigma Yhteiskunnallisen ajattelun ja toiminnan uusi suunta täyttyvällä maapallolla. Sosiaalipedagoginen aikakauskirja 2014;15.

(20) Rainham D, Cantwell R, Jason T. Nature approapriation and associations with population health in Canada's largest cities. IJER 2013;10:1268-1283. https://doi.org/10.3390/ijerph10041268

(21) Jorgenson A, Dietz T. Economic growth does not reduce the ecological intensity of human well-being. Sustain Sci 2015;10:149-156. https://doi.org/10.1007/s11625-014-0264-6

(22) Sieswerda L, Soskolne C, Newman S, ym. Toward measuring the impact of ecological disintegrity on human health. Epidemiology 2001;12: 28-32.

https://doi.org/10.1097/00001648-20010100000006

(23) Duit A. The four faces of the environmental state: environmental governance regimes in 28 countries. Environmental Politics 2016;25:6991.

https://doi.org/10.1080/09644016.2015.10776 19

(24) Meadowcroft J. Engaging with the politics of sustainable transitions. Environmental Innovation and Social Transitions 2011;1:7075

https://doi.org/10.1016/j.eist.2011.02.003

(25) Duit A, Feindt P, Meadowcroft J. Greening Leviathan: the rise of the environmental state? Environ Polit2016;25:1-23. https://doi.org/10.1080/09644016.2015.1085 218
(26) Gough I. Welfare states and environmental states: a comparative analysis. Environ Polit 2016;25:24-47.

https://doi.org/10.1080/09644016.2015.10743 82

(27) Sommerer T, Lim S. The environmental state as a model for the world? An analysis of policy repertoires in 37 countries. Environ Polit 2016;25:92-115.

https://doi.org/10.1080/09644016.2015.10817 19

(28) Massa I. Vihreä Sopimus uutena yhteiskuntapolitiikan strategiana. Janus 2009;17:231-247.

(29) Huh T, Kim Y, Kim JH. Towarsd a green state: a comparative study on OECD countries through fuzzy-set analysis. Sustainability 2018;10:3181. https://doi.org/10.3390/su10093181

(30) Koch M, Fritz M. Building the eco-social state: Do welfare regimes matter? J Soc Policy 2014;43:679-703. https://doi.org/10.1017/S004727941400035X

(31) Lim S, Duit A. Partisan politics, welfare states, and environmental policy outputs in the OECD countries, 1975-2005. Regul Gov 2018;12:220237. https://doi.org/10.1111/rego.12138

(32) Helne T, Hirvilammi T \& Alhanen K. (toim.) Kriisi-istunto: dialogi ekologiseen hyvinvointivaltioon siirtymisestä. Kelan tutkimusosasto. Tampere; Juvenes Print: 2014.

(33) Esping-Andersen. The three worlds of welfare capitalism. Cambridge; Polity Press: 1990.

(34) Dryzek J, Stevenson H. Global democracy and earth system governance. Ecol Econ, 2011;70:1865-1874. https://doi.org/10.1016/j.ecolecon.2011.01.021

(35) Kitzes J, Wackernagel M. Answers to common questions in ecological footprint accounting. Ecol indic 2009;9:812-817. https://doi.org/10.1016/j.ecolind.2008.09.014

(36) UN IGME 2018. The UN Inter-agency Group for Child Mortality Estimation (UN IGME) in 2018. Luettu 15.1.2019. https://childmortality. org/data

(37) Fanning A, O’Neill D. The wellbeingcomsumption paradox: happiness, health, income, and carbon emissions in growing versus non-growing economies. J Clean Prod 2019;212:810-821. https://doi.org/10.1016/j.jclepro.2018.11.223

(38) Wei XZ. China's excess males, sex selective abortion, and one child policy: analysis of data from 2005 national intercensus survey. BMJ 2009;338:b1211. https://doi.org/10.1136/bmj.b1211

(39) McGuire J. Wealth, Health, and Democracy in East Asia and Latin America. Cambridge University: Press; 2010. https://doi.org/10.1017/CBO9780511750656 
(40) Shen C, Williamson JB. Accounting for CrossNational Differences in Infant Mortality Decline (1965-1991) among Less Developed Countries: Effects of Women's Status, Economic Dependency, and State Strength. Soc Indic Res 2001;53:257-288. https://doi.org/10.1023/A:1007190612314

(41) Brady D, Kaya Y, Beckfield J. Reassessing the Effect of Economic Growth on Wellbeing in Less-Developed Countries, 1980-2003. Studies in Comparative International Development 2007;42:1-35.

https://doi.org/10.1007/s12116-007-9003-7

(42) Hanmer L, Lensink R, White H. Infant and Child Mortality in Developing Countries: Analysing the Data for Robust Determinants. J Dev Stud 2003;40:101-118. https://doi.org/10.1080/00220380412331293 687

(43) Lähde V. Niukkuuden maailmassa. Tampere; Eurooppalaisen filosofian seura \& Niin\&Näin; 2013.

(44) Nurmela J. Kotitalouksien päästöt ovat laskusuunnassa. Tilastokeskus, Asiantuntija-artikkelit ja ajankohtaisblogit 2018. Luettu 20.9.2019. https://www.stat.fi/tietotrendit/artikkelit/2018/ kotitalouksien-aiheuttamat-paastot-ovatlaskusuunnassa/

(45) Roy SN. Multi-level determinants of regional variations in infant mortality in India: A state level analysis. Int J Child Health Hum Dev 2013;6:173-191.

JUTTA PULKKI

TtT, dosentti, tutkijatohtori

Tampereen yliopisto

Yhteiskuntatieteiden tiedekunta, terveystieteet

Mikкo PERKiö

YTT, yliopistotutkija

Tampereen yliopisto

Yhteiskuntatieteiden tiedekunta, terveystieteet

\section{LAURI KOKKINEN}

TtT, dosentti, yliopistolehtori

Tampereen yliopisto

Yhteiskuntatieteiden tiedekunta, terveystieteet 
Liitetaulukko 1. Ajallinen muutos ekologisessa kuormassa, elinajanodotteessa ja imeväiskuolleisuudessa 33 maassa.

\begin{tabular}{|c|c|c|c|c|c|c|c|c|c|}
\hline \multirow[b]{2}{*}{ Ajanjakso } & \multicolumn{3}{|c|}{ Ekologinen kuorma } & \multicolumn{3}{|c|}{ Elinajanodote } & \multicolumn{3}{|c|}{ Imeväiskuolleisuus } \\
\hline & $\begin{array}{c}1961- \\
1965\end{array}$ & $\begin{array}{c}1986- \\
1990\end{array}$ & $\begin{array}{c}2010- \\
2014\end{array}$ & $\begin{array}{c}1960- \\
1966\end{array}$ & $\begin{array}{c}1985- \\
1991\end{array}$ & $\begin{array}{c}2009 \\
2015\end{array}$ & $\begin{array}{c}1960- \\
1966\end{array}$ & $\begin{array}{c}1985- \\
1991\end{array}$ & $\begin{array}{r}2009 \\
2015\end{array}$ \\
\hline Australia & 7,6 & 7,4 & 7,9 & 0 & 6,8 & 4,6 & 9,9 & 23,7 & 23,8 \\
\hline Belgia & 6,2 & 7,0 & 7,0 & 3,3 & 6,6 & 4,8 & 21,0 & 19,2 & 13,5 \\
\hline Brasilia & 2,4 & 2,9 & 3,1 & 6,7 & 6,0 & 6,8 & 13,2 & 19,9 & 20,0 \\
\hline Chile & 2,4 & 2,7 & 4,2 & 6,3 & 8,1 & 4,6 & 33,7 & 20,1 & 13,0 \\
\hline Espanja & 2,5 & 4,2 & 4,1 & 6,3 & 3,0 & 7,3 & 28,6 & 22,8 & 18,2 \\
\hline Etelä-Afrikka & 2,8 & 3,5 & 3,4 & 4,5 & 6,2 & 14,2 & $*$ & 16,3 & 21,3 \\
\hline Hollanti & 4,1 & 5,8 & 6,1 & 0,5 & 3,0 & 4,9 & 14,5 & 16,5 & 10,5 \\
\hline Intia & 0,6 & 0,7 & 1,1 & 6,5 & 5,8 & 6,2 & 7,6 & 14,3 & 25,5 \\
\hline Irlanti & 5,1 & 5,8 & 4,7 & 2,8 & 4,8 & 6,4 & 23,1 & 19,1 & 13,9 \\
\hline Iso-Britannia & 6,5 & 5,9 & 5,0 & 1,5 & 5,7 & 4,5 & 14,4 & 31,1 & 17,4 \\
\hline Israel & 2,7 & 4,5 & 5,6 & 1,0 & 6,3 & 3,5 & $*$ & 24,0 & 21,1 \\
\hline Italia & 2,7 & 5,0 & 4,8 & 5,8 & 6,3 & 4,9 & 22,4 & 22,9 & 11,8 \\
\hline Itävalta & 3,8 & 5,1 & 6,1 & 4,6 & 6,9 & 4,4 & 26,6 & 29,0 & 18,9 \\
\hline Japani & 3,2 & 5,2 & 4,8 & 10,3 & 6,4 & 5,1 & 42,1 & 18,2 & 12,5 \\
\hline Kanada & 8,7 & 9,4 & 8,3 & 3,0 & 5,3 & 4,8 & 20,5 & 17,5 & 6,0 \\
\hline Kiina & 0,9 & 1,5 & 3,6 & 14,2 & 3,1 & 4,2 & $*$ & 1,2 & 37,0 \\
\hline Korea & 0,9 & 3,1 & 5,9 & 7,1 & 10,4 & 5,1 & 24,0 & 40,8 & 18,9 \\
\hline Kreikka & 2,1 & 4,7 & 4,6 & 5,3 & 8,3 & 4,3 & 13,9 & 33,1 & $-18,0$ \\
\hline Meksiko & 1,9 & 2,4 & 2,8 & 6,4 & 7,8 & 4,1 & 16,9 & 21,4 & 17,0 \\
\hline Norja & 7,9 & 8,5 & 5,8 & 1,7 & 4,4 & 7,9 & 16,3 & 22,9 & 18,5 \\
\hline Portugali & 2,5 & 3,8 & 3,9 & 7,0 & 4,4 & 11,3 & 24,6 & 35,8 & 6,3 \\
\hline Puola & 4,1 & 5,6 & 4,6 & 6,6 & 0,1 & 7,2 & 34,4 & 16,9 & 22,2 \\
\hline Ranska & 4,6 & 5,4 & 5,0 & 3,6 & 6,3 & 4,9 & 25,3 & 16,5 & 0,0 \\
\hline Ruotsi & 7,7 & 6,7 & 6,5 & 4,0 & 4,3 & 4,6 & 20,2 & 14,1 & 7,7 \\
\hline Saksa & 4,7 & 6,7 & 5,2 & 3,1 & 4,9 & 6,1 & $*$ & 29,3 & 8,3 \\
\hline Suomi & 6,8 & 7,0 & 6,2 & 2,1 & 3,9 & 8,7 & 28,2 & 11,7 & 23,1 \\
\hline Sveitsi & 4,6 & 6,2 & 5,2 & 3,6 & 3,4 & 4,8 & 18,9 & 12,3 & 5,0 \\
\hline Tanska & 6,5 & 8,9 & 6,6 & 1,0 & 2,9 & 9,8 & 20,7 & 13,8 & $-2,9$ \\
\hline Turkki & 1,6 & 2,4 & 3,3 & 8,0 & 8,0 & 9,5 & 17,5 & 25,5 & 34,1 \\
\hline Unkari & 3,3 & 4,8 & 3,3 & 5,7 & 1,3 & 6,4 & 18,3 & 25,5 & 18,9 \\
\hline Uusi-Seelanti & 4,9 & 4,9 & 5,4 & $-0,4$ & 8,4 & 3,9 & 19,0 & 23,0 & 11,5 \\
\hline Venäjä & $*$ & $*$ & 5,6 & 5,2 & 1,9 & 8,0 & $*$ & 12,8 & 12,0 \\
\hline Yhdysvallat & 8,4 & 9,8 & 8,5 & 1,5 & 3,2 & 1,4 & 12,4 & 14,2 & 9,4 \\
\hline
\end{tabular}

*Tieto puuttuu 